Article

\title{
Ancylostoma ceylanicum: The Neglected Zoonotic Parasite of Community Dogs in Thailand and Its Genetic Diversity among Asian Countries
}

\author{
Doolyawat Kladkempetch ${ }^{1}$, Sahatchai Tangtrongsup ${ }^{2,3}$ and Saruda Tiwananthagorn ${ }^{4,5, *}$ (i) \\ 1 Master's Degree Program in Veterinary Science, Faculty of Veterinary Medicine, Chiang Mai University, \\ Chiang Mai 50100, Thailand; doolyawat_kl@cmu.ac.th \\ 2 Department of Companion Animal and Wildlife Clinic, Faculty of Veterinary Medicine, \\ Chiang Mai University, Chiang Mai 50100, Thailand; sahatchai.t@cmu.ac.th \\ 3 Research Center of Producing and Development of Products and Innovations for Animal Health and \\ Production, Faculty of Veterinary Medicine, Chiang Mai University, Chiang Mai 50100, Thailand \\ 4 Department of Veterinary Biosciences and Veterinary Public Health, Faculty of Veterinary Medicine, \\ Chiang Mai University, Chiang Mai 50100, Thailand \\ 5 Excellent Center in Veterinary Bioscience, Faculty of Veterinary Medicine, Chiang Mai University, \\ Chiang Mai 50100, Thailand \\ * Correspondence: saruda.t@cmu.ac.th; Tel.: +66-53-948-046 or +66-95-446-5955
}

Received: 3 November 2020; Accepted: 17 November 2020; Published: 19 November 2020

Simple Summary: Ancylostomiasis is a zoonotic disease caused by the Ancylostoma hookworm infection of dogs, cats, and other wildlife species and is frequently found in Asia and tropical regions. The present study had confirmed the species of hookworm in dogs and soil environments collected from temple communities. In addition, we investigated the association of hookworm-contaminated soil in temple areas to increase awareness and establish a regimen to prevent zoonotic hookworm transmission. Lastly, we analyzed the genetic diversity and evolution of hookworm in dogs and soil environments among Thai A. ceylanicum and other Asian populations and disclosed insight into their fundamental genetic relationship.

Abstract: Ancylostoma ceylanicum is a zoonotic helminth that is commonly found in domestic dogs and cats throughout Asia but is largely neglected in many countries. This study aimed to confirm the species of hookworm in dogs and soil environments and investigate the evolutionary analyses of A. ceylanicum among Thai and Asian populations. In a total of 299 dog fecal samples and 212 soil samples from 53 temples, the prevalence rates of hookworm infection by microscopic examination were $26.4 \%$ (79/299) and 10.4\% (22/212) in dog and soil samples, respectively. A PCR-RFLP targeting the ITS region was then utilized to identify the hookworm species. In dogs, A. ceylanicum was the main hookworm species, and the rates of $A$. ceylanicum and A. caninum infections were $96.6 \%$ and $3.5 \%$, respectively. The genetic characterization and diversity indices of the $A$. ceylanicum cox 1 gene among Thai and Asian populations were evaluated. Nine haplotypes were identified from Thai A. ceylanicum, in which the haplotype diversity and the nucleotide diversity were 0.4436 and 0.0036 , respectively. The highest nucleotide diversity of Chinese $A$. ceylanicum populations suggested that it could be the ancestor of the populations. Pairwise fixation indices indicated that Thai A. ceylanicum was closely related to the Malaysian population, suggesting a gene flow between these populations. The temples with hookworm-positive dogs were associated with the presence of hookworm-contaminated soil, as these levels showed an approximately four-fold increase compared with those in temples with hookworm-negative dogs ( $\mathrm{OR}=4.38,95 \% \mathrm{CI}$ : 1.55-12.37). Interestingly, the genotypes of A. ceylanicum in the contaminating soil and infecting dogs were identical. Therefore, increased awareness and concern from the wider public communities with regard to the responsibility of temples and municipal offices to provide proper deworming programs to community dogs should be strongly endorsed to 
reduce the risk of the transmission of this zoonotic disease. In addition, parasitic examination and treatment should be strongly implemented before dogs are imported and exported worldwide.

Keywords: Ancylostoma ceylanicum; community dogs; ITS region; cox1; Thailand; population diversity

\section{Introduction}

Hookworms are soil-transmitted gastrointestinal nematodes of the Ancylostomatidae family that infect dogs, cats, and humans. These nematodes are endemic in tropical and subtropical regions of the world, including parts of China, Southeast Asia, Australia, and Africa [1-4]. Hookworms can infect the host by the fecal-oral route and through the skin penetration of the third-stage larvae [2]. Hookworm infection causes intestinal blood loss, anemia, malnutrition, and dermatitis [5]. Common species of hookworm infection in dogs include Ancylostoma caninum, A. ceylanicum, A. braziliense, and Uncinaria stenocephala, while $A$. braziliense, A tubaeforme, A. ceylanicum, and $U$. stenocephala are commonly found in cats $[6,7]$. Recent studies have shown that ancylostomiasis in humans results from Necator americanus, A. duodenale, and A. ceylanicum [5,8,9]. Among Ancylostoma species, A. ceylanicum is the only species of animal hookworms known to produce patent infections in humans and is an important cause of zoonotic ancylostomiasis in Asia and Southeast Asia [9-14].

In general, the epidemiological study revealed that animal-derived Ancylostoma species are emerging due to human and animal interaction $[15,16]$. In Thailand, free-roaming community dogs have been widespread and come in close contact with people in some areas, such as temples and rural communities. The presence of hookworm larvae in soil reported by George et al. [5] confirmed that humans and dogs are at risk of infection from hookworm-contaminated soil. Additionally, a previous report in Malaysia from Ngui et al. [15] indicated that people who are not wearing shoes are at risk of hookworm infection from hookworm-contaminated soil. The opportunity for exposure to hookworm is high in children, farmers, and especially Buddhist monks, who do not wear shoes based on their practices and Buddhist tradition in Thai temples. Information regarding whether the soil in the area is contaminated with hookworm is, therefore, important for public health to promote awareness and establish a regimen to prevent zoonotic hookworm transmission.

The conventional method for hookworm diagnosis is coprological examination. However, this method cannot differentiate hookworm species due to the similar egg size and morphology. Morphological identification of adult hookworms is achievable, but the process is time-consuming and labor-intensive and requires personal skill [16]. Alternatively, molecular techniques have been developed for the identification of hookworms at the species level, such as polymerase chain reaction (PCR) assays and PCR with restriction fragment length polymorphism (PCR-RFLP) assays targeting the internal transcribed spacer (ITS) region [16]. The ITS region is a conserved region with a low mutation rate and has no intraspecific variation [17]. Thus, the ITS region is suitable as a genetic marker for hookworm species identification [18]. Recently, the cytochrome $c$ oxidase subunit 1 (cox1) gene has been utilized to evaluate the evolution and relationship of hookworm species among the population [19,20], given its high intraspecific sequence variation from maternal inheritance and high evolutionary rates [21].

In Northern Thailand, a few reports have assessed the prevalence of hookworm infection in humans, domestic dogs, and cats. By microscopic examination, hookworm infection rates of approximately $21.3 \%$ in dogs and $13.9 \%$ in cats [22] and $12 \%$ in dogs and $4.5 \%$ in cats [23] have been reported in the lower northern region and in the Chiang Mai province of the upper northern region, respectively. The prevalence of hookworm infection in humans ranged from $0.6 \%$ to $13.4 \%$ [24,25]. However, the species of hookworm in Upper Northern Thailand have never been clarified. The present study, therefore, aimed to identify the species of hookworm in dogs and investigate the presence of hookworm contamination in the soil environment of community temples where there are high risks of communicable pathogen transmission. Furthermore, the genetic characteristics of Ancylostoma 
hookworm and the evolutionary genetic relationships among the Thai hookworm and the populations of neighboring Asian countries have been elucidated.

\section{Materials and Methods}

\subsection{Study Area and Sample Size}

The study area is located in the upper northern region of Thailand. Four provinces, including Chiang Mai $\left(18^{\circ} 47^{\prime} 26^{\prime \prime} \mathrm{N}, 98^{\circ} 59^{\prime} 14^{\prime \prime} \mathrm{E}\right)$, Chiang Rai ( $\left.20^{\circ} 01^{\prime} 05^{\prime \prime} \mathrm{N}, 99^{\circ} 40^{\prime} 22^{\prime \prime} \mathrm{E}\right)$, Lampang $\left(18^{\circ} 17^{\prime} 21^{\prime \prime} \mathrm{N}, 99^{\circ} 29^{\prime} 26^{\prime \prime} \mathrm{E}\right)$, and Phayao $\left(19^{\circ} 11^{\prime} 30^{\prime \prime} \mathrm{N}, 99^{\circ} 52^{\prime} 47^{\prime \prime} \mathrm{E}\right)$, were chosen and considered as high dog population density provinces (Figure 1). Sampling sites were 53 community temples that were chosen based on convenience and distribution from at least 3 districts in each province. The inclusion criteria for temple selection were (i) a human population density of more than 30 persons per sq. km. [26,27], (ii) no regular deworming program in dogs within 3 months, and (iii) ease of access and sample transportation to the laboratory. The sample size of $299 \mathrm{dog}$ fecal samples for the detection of hookworm infection was calculated using the Win episcope 2.0 program [28] based on an estimated hookworm prevalence of $12.8 \%$ in dogs [29] and an error rate of $5 \%$ with a $95 \%$ level of confidence. The stratified sampling method was used to generate the number of samples per province based on dog population data [30].

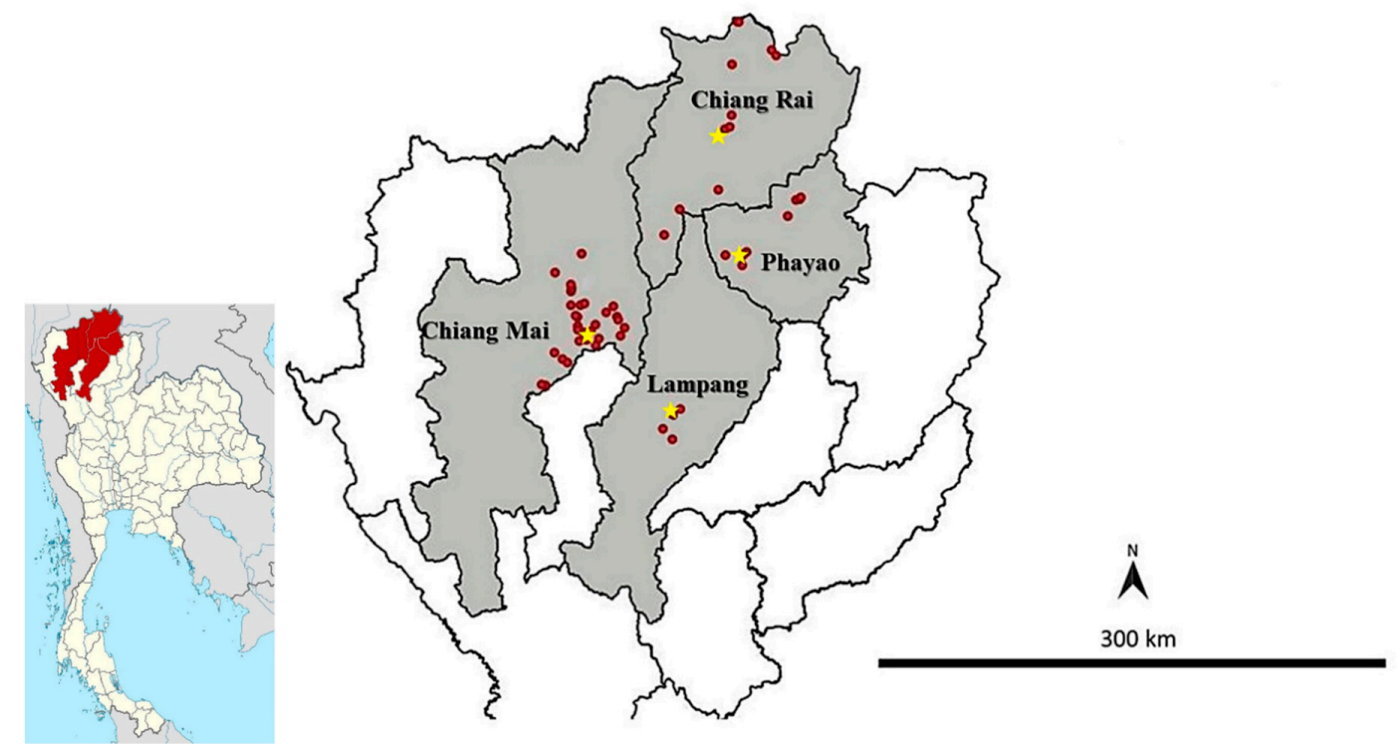

Figure 1. Map of the study areas in Thailand. The gray color indicates four study provinces, red dots indicate the location of sampling sites (temples), and stars indicate the capital city of each province.

All the owners signed an informed consent form, and the animal use was approved by the Ethics Committee of the Laboratory Animal Center, Faculty of Veterinary Medicine, Chiang Mai University (S41/2561), on 18 January 2019.

\subsection{Sample Collection and Examination}

\subsubsection{Fecal and Soil Sample Collection}

Samples were collected between June and September 2019. Two hundred and ninety-nine fecal samples were collected from the rectum of dogs or fresh fecal samples found on the ground. All the collected fresh feces were normal in appearance (medium to dark brown in color, soft to firm in texture) based on the WALTHAM fecal scoring system [31]. The dog ID, date of collection, temple name, district, province, cleaning housing program, and type of food were recorded. Soil environment samples were collected at the temple in the morning (08:00-10:00). For soil sample collection, the sites of sample collection were defined by 4 areas in each temple: (i) temple courtyard, (ii) dog dwelling 
area, (iii) human activity area (such as sand pagoda), and (iv) under the big tree. In the collection site that was not dirt ground, the soil sample for that site was obtained from the adjacent ground within a $2 \mathrm{~m}$ radius of the area. Soil samples were collected from moist areas within the selected sampling sites, and approximately $50 \mathrm{~g}$ (wet weight) was obtained by scraping the surface layer to gather a 0.09 square meter area using a metal spade. The soil samples were kept separately in a sealed plastic bag.

All the samples were stored on ice and transported to the Parasitology Laboratory, Faculty of Veterinary Medicine, Chiang Mai University. Samples were refrigerated at $4{ }^{\circ} \mathrm{C}$ upon arrival.

\subsubsection{Microscopic Examinations of Fecal and Soil Samples}

Fresh fecal samples were examined under a light microscope after simple floatation using zinc sulfate solution (specific gravity: 1.18) for the presence of eggs. The remainder of the fecal sample was stored at $-20{ }^{\circ} \mathrm{C}$ until further molecular analysis. The Baermann technique was used to determine the presence of hookworm-like larvae in the soil samples [32]. Twenty grams of soil samples were primarily filtered through a tea strainer to remove any debris and then subjected to another filtration step using 2 sieve filters with pore sizes of 0.4 and $0.2 \mathrm{~mm}$. The filtrated soil sample was cultured individually using tap water. Hookworm-like larvae containing sediments were stored at $-20{ }^{\circ} \mathrm{C}$ until further molecular analysis could be carried out.

\subsection{DNA Extraction}

Genomic DNA (gDNA) samples from hookworm-positive samples were extracted using the NucleoSpin ${ }^{\circledR}$ DNA stool kit (Macherey-Nagel GmbH, Düren, Germany) according to the manufacturer's instructions. In the elution step, gDNA samples were eluted with $100 \mu \mathrm{L}$ of elution buffer. The extracted DNA concentration and quality were determined using a spectrophotometer (Beckman Coulter DU ${ }^{\circledR}$ 730 Life Sciences, Pasadena, CA, USA) at wavelengths of 260 and $280 \mathrm{~nm}$. All the gDNA samples were kept at $-20{ }^{\circ} \mathrm{C}$ until the next step.

\subsection{Molecular Analyses}

2.4.1. Identification of Hookworm Species Using a Polymerase Chain Reaction-Restriction Fragment Length Polymorphism (PCR-RFLP) Assay Based on ITS Region

The PCR-RFLP assay, which was established by Traub et al. [16], was conducted to identify the species of hookworm in the positive dog fecal and soil samples. A forward primer RTGHF1 (5'-CGTGCTAGTCTTCAGGACTTTG-3') and a reverse primer RTABCR1 (5'-CGGGAATTGCTATAAGCAAGTGC-3') were used to amplify the 545-bp region of the internal transcribed spacer (ITS1, 5.8S, and ITS2). PCR amplification reactions were performed in a $25 \mu \mathrm{L}$ reaction volume containing $10 \mathrm{ng}$ of template gDNA $(2-4 \mu \mathrm{L}), 0.2 \mu \mathrm{M}$ of each primer $(0.5 \mu \mathrm{L}$ of $10 \mu \mathrm{M})$, and $12.5 \mu \mathrm{L}$ of $2 \times$ PCR Master Mix (KOD One ${ }^{\mathrm{TM}}$ PCR Mastermix; Toyobo, Japan). The thermocycling conditions were as follows: initial denaturation at $94{ }^{\circ} \mathrm{C}$ for $2 \mathrm{~min}, 45$ cycles of amplification $\left(94^{\circ} \mathrm{C}\right.$ for $30 \mathrm{~s}, 62^{\circ} \mathrm{C}$ for $30 \mathrm{~s}$, and $72{ }^{\circ} \mathrm{C}$ for $30 \mathrm{~s}$ ), and a final extension at $72{ }^{\circ} \mathrm{C}$ for $5 \mathrm{~min}$. The reaction was performed on a $1100^{\mathrm{TM}}$ Thermal Cycler (Bio-Rad, Hercules, CA, USA). The amplified PCR products were digested with Hinf1 to differentiate $A$. caninum from A. ceylanicum and $U$. stenocephala. The digestions were performed at $37^{\circ} \mathrm{C}$ for $16 \mathrm{~h}$, using 1 unit of restriction enzyme and $1 \mu \mathrm{g}$ of DNA (3-5 $\mu \mathrm{L}$ of PCR product) in a total reaction volume of $20 \mu \mathrm{L}$. The PCR products were analyzed using $2 \%$ agarose gels electrophoresis. Distilled water (DW) and the gDNA of A. caninum and A. ceylanicum were used as a negative and positive control, respectively.

\subsubsection{PCR Assay and Nucleotide Analysis Based on A. ceylanicum and A. caninum cox1 Gene}

The mitochondrial cox 1 gene served as the target to assess the genetic characteristics and evolutionary analysis. The previously identified A. ceylanicum- and A. caninum-positive samples were 
successively subjected to PCR for the cox1 gene using a set of primers described by Inpankaew et al. [33], including the forward primer AceyCOX1F (5'-GCTTTTGGTATTGTAAGACAG-3') and the reverse primer AceyCOX1R (5'-CTAACAACATAATAAGTATCATG-3'), amplifying a 377-bp amplicon. The reactions were performed in a $50 \mu \mathrm{L}$ reaction mixture volume, containing $10 \mathrm{ng}$ of template gDNA $(2-4 \mu \mathrm{L}), 0.2 \mu \mathrm{M}$ of each primer $(1 \mu \mathrm{L}$ of $10 \mu \mathrm{M})$, and $25 \mu \mathrm{L}$ of $2 \times$ PCR Master Mix (KOD One ${ }^{\mathrm{TM}}$ PCR Mastermix; Toyobo, Japan). The PCR conditions were set as follows: initial denaturation at $94{ }^{\circ} \mathrm{C}$ for $2 \mathrm{~min}, 45$ cycles of amplification $\left(94{ }^{\circ} \mathrm{C}\right.$ for $30 \mathrm{~s}, 55{ }^{\circ} \mathrm{C}$ for $30 \mathrm{~s}$, and $68{ }^{\circ} \mathrm{C}$ for $45 \mathrm{~s}$ ), and a final extension at $72{ }^{\circ} \mathrm{C}$ for $5 \mathrm{~min}$. The reaction was performed using a $\mathrm{T} 100^{\mathrm{TM}} \mathrm{Thermal}$ Cycler (Bio-Rad, Hercules, CA, USA). The DW and gDNA of A. caninum and A. ceylanicum were used as negative and positive controls, respectively. The PCR products were purified using a NucleoSpin ${ }^{\circledR}$ PCR Clean-up Kit (Macherey-Nagel GmbH, Düren, Germany). Purified PCR products were submitted for fluorescent dye-terminator sequencing by Bio Basic, Inc. (Singapore, Singapore) in the sense and antisense directions using the PCR primer set described above. For nucleotide analysis, the cox 1 amplicons of 32 samples (29 A. ceylanicum samples from dogs, 2 A. ceylanicum samples from soil, and 1 A. caninum sample from dog) were selected based on the geographic distribution, covering all positive provinces.

\subsection{Data Analyses}

\subsubsection{Prevalence of Hookworm Infection/Contamination}

Positive fecal samples from the zinc sulfate flotation technique and positive soil samples from the Baermann technique were considered as positive for hookworm detection. The prevalence of hookworm infection in dogs and contamination in soil samples were estimated using the formula prevalence $=$ (number of positives samples divided by the number of samples in dogs/soil examined $) \times 100$. The association between hookworm-positive results and sampling areas was assessed using Fisher's exact test. The significance was defined as $p<0.05$.

\subsubsection{Phylogenetic Analysis}

The cox 1 sequences were edited and manually aligned. The consensus sequences were generated using the BioEdit Sequence Alignment Editor [34] and then compared with the nucleotide sequences from GenBank using a Basic Local Alignment Search Tool (BLAST) analysis. Phylogenetic analysis was performed using MEGA X [35]. Multiple sequences were aligned using ClustalW (https:// www.genome.jp/tools-bin/clustalw), and phylogenetic analysis was performed using a maximum likelihood (ML) method based on the Kimura 2-Parameter model. The consensus tree was obtained after a 1000-replication bootstrap analysis. The cox 1 sequences of $A$. ceylanicum from other areas of Thailand and other countries, including Malaysia, Cambodia, China, Japan, Papua New Guinea, Australia, and Tanzania, and A. caninum from Australia (NC012309) were used as reference sequences for tree construction (Table S1). In addition, the sequence of $A$. duodenale from China (accession number: NC003415) was used as an outgroup species.

\subsubsection{Population Genetic Analysis}

The DnaSP 6 program [36] was used for the haplotype analysis and calculations to determine the haplotype diversity $(\mathrm{Hd})$, nucleotide diversity $(\pi)$, and the number of variable sites $(S)$. The gene flow among populations was analyzed by fixation index $\left(\mathrm{F}_{\mathrm{ST}}\right)$ statistics using the Arlequin program Version 3.5 [37]. The gene flow of A. ceylanicum was analyzed using the reference sequences from Asian countries, including Thailand, China, Malaysia, and Cambodia (Table S2). The Network program [38] was used to generate a median-joining (MJ) network of cox1 haplotypes and reference haplotypes and was subsequently drawn manually. The references haplotype and their frequency obtained from the NCBI database (https://www.ncbi.nlm.nih.gov/genbank/) are described above. 


\section{Results}

\subsection{Prevalence and Distribution of Hookworm Infection}

A total of 299 fecal samples and 212 soil samples from 53 temples were examined microscopically, and the hookworm species were identified by PCR-RFLP targeting the ITS region. The prevalence rate of hookworm in dogs was $26.4 \%$ (79/299), as assessed by microscopic examination. PCR-RFLP successfully identified the species of hookworm in 58 samples, and the rates of A. ceylanicum and A. caninum infection were $96.55 \%$ (56/58) and 3.45\% (2/58), respectively (Figure 1). On the other hand, the prevalence of hookworm-like larvae in soil was $10.38 \%$ (22/212), as assessed by microscopic examination (Table 1). However, PCR-RFLP only identified the species in 8 of 22 samples, and all the samples were identified as A. ceylanicum (Table 1).

Table 1. Summary of hookworm infection in dog fecal samples and soil samples in Thailand, as demonstrated by the microscopic results and subsequent PCR-RFLP targeting the ITS region.

\begin{tabular}{|c|c|c|c|c|c|c|c|c|c|c|c|c|c|c|c|c|c|c|}
\hline \multirow{3}{*}{ Province } & \multicolumn{9}{|c|}{ Fecal Samples } & \multicolumn{9}{|c|}{ Soil Samples } \\
\hline & \multicolumn{3}{|c|}{$\begin{array}{c}\text { Positive } \\
\text { Microscopic }\end{array}$} & \multirow[t]{2}{*}{$\mathbf{N}_{2}$} & \multicolumn{2}{|c|}{$\begin{array}{c}A . \\
\text { ceylanicum }\end{array}$} & \multicolumn{2}{|c|}{$\begin{array}{c}\text { A. } \\
\text { caninum }\end{array}$} & \multirow{2}{*}{$\begin{array}{c}\text { n/a } \\
n\end{array}$} & \multicolumn{3}{|c|}{$\begin{array}{c}\text { Positive } \\
\text { Microscopic }\end{array}$} & \multirow[t]{2}{*}{$\mathbf{N}_{4}$} & \multicolumn{2}{|c|}{$\begin{array}{c}A . \\
\text { ceylanicum }\end{array}$} & \multicolumn{2}{|c|}{$\begin{array}{c}A . \\
\text { caninum }\end{array}$} & \multirow{2}{*}{$\begin{array}{c}\text { n/a } \\
n\end{array}$} \\
\hline & $\mathrm{N}_{1}$ & $n$ & $\%$ & & $n$ & $\%$ & $n$ & $\%$ & & $\mathrm{~N}_{3}$ & $n$ & $\%$ & & $n$ & $\%$ & $n$ & $\%$ & \\
\hline Chiang Mai & 159 & 57 & $35.85^{a}$ & 42 & 40 & 95.24 & 2 & 4.76 & 15 & 120 & 16 & 13.33 & 3 & 3 & 100 & 0 & 0 & 13 \\
\hline Chiang Rai & 70 & 6 & $8.57^{\mathrm{b}}$ & 5 & 5 & 100 & 0 & 0 & 1 & 48 & 1 & 2.08 & 1 & 1 & 100 & 0 & 0 & 0 \\
\hline Lampang & 20 & 9 & $45.00^{\mathrm{a}}$ & 5 & 5 & 100 & 0 & 0 & 4 & 16 & 3 & 18.75 & 2 & 2 & 100 & 0 & 0 & 1 \\
\hline Phayao & 50 & 7 & $14.00^{b}$ & 6 & 6 & 100 & 0 & 0 & 1 & 28 & 2 & 7.14 & 2 & 2 & 100 & 0 & 0 & 0 \\
\hline Total & 299 & 79 & 26.42 & 58 & 56 & 96.55 & 2 & 3.45 & 21 & 212 & 22 & 10.38 & 8 & 8 & 100 & 0 & 0 & 14 \\
\hline
\end{tabular}

$\mathrm{N}_{1}$ : total number of examined dog fecal samples assessed by microscopic examination; $\mathrm{N}_{2}$ : number of positive dog samples successfully assessed with PCR-RFLP; $\mathrm{N}_{3}$ : total number of examined soil samples by microscopic examination; $\mathrm{N}_{4}$ : number of positive soil samples successfully assessed with PCR-RFLP; n/a: species unidentified samples; superscripts $(a, b)$ indicate test results of Chi-square on prevalence among four provinces (any measurements with shared superscript letters are not significantly different from each other at $p<0.05$ ).

Considering the population, the temple-level prevalence of positive dogs and positive soils was $47.17 \%$ (25/53) and 26.42\% (14/53), respectively (Table S3). A total of 10 temples were positive for hookworm both in dog and soil samples (Table S3). Although not statistically significant, the hookworm-positive results in dogs were speculated to be associated with the hookworm-positive results in the soil $(p=0.06)$. Regarding the different areas in each temple, we found that the soil from dog-dwelling areas had the highest rates of hookworm contamination $(15.09 \%, 8 / 53)$, followed by the soil from human activity areas, such as sand pagoda $(11.32 \%$; 6/53); the areas under big trees $(9.43 \%$; 5/53); and the temple courtyard $(5.66 \%, 3 / 53)$ (Table S4). However, the frequency of hookworm-contaminated soil in each sampling site in the temple exhibited no significant differences ( $p>0.05$; Fisher's exact).

\subsection{Hookworm Species Confirmation and Genetic Characteristics of the A. ceylanicum Mitochondrial cox1 Gene}

The nucleotide BLAST of partial cox1 sequences ( $315 \mathrm{bp}$ ) of 31 A. ceylanicum sequences exhibited a high identity (98.07-100\%) with Thai A. ceylanicum (GenBank accession no. KF896595). An A. caninum sequence from a dog exhibited a $96.71 \%$ identity with $A$. caninum from Australia (GenBank accession no. AJ407962). The obtained A. ceylanicum cox 1 gene sequences from dog and soil isolates were classified into nine haplotypes, which were referred to as Acy-COX1-TH01 to Acy-COX1-TH09. The sequences of A. ceylanicum of dogs and soil were deposited in GenBank (DDBJ/EMBL/GenBank database accession no. LC533318-LC533327). The sequence of A. caninum was deposited as LC533328 (Table S5).

Genetic variation among nine haplotypes of Thai $A$. ceylanicum, as assessed by multiple alignment analysis, revealed 12 different variable sites, including 2 transversions and 10 transitions (Table 2). 
Table 2. Multiple alignment of the partial cox 1 from 9 haplotypes of $A$. ceylanicum in this study.

\begin{tabular}{|c|c|c|c|c|c|c|c|c|c|c|c|c|}
\hline \multirow{2}{*}{$\begin{array}{l}\text { Haplotype } \\
\text { Name }\end{array}$} & \multicolumn{12}{|c|}{ Nucleotide Position on the A. ceylanicum cox 1 Gene } \\
\hline & 48 & 72 & 87 & 88 & 90 & 105 & 147 & 150 & 198 & 199 & 219 & 264 \\
\hline Acy-COX1-TH01 & A & $\mathrm{C}$ & A & G & A & A & G & A & G & G & A & G \\
\hline Acy-COX1-TH02 & G & . & . & . & . & . & $\mathrm{A}$ & . & . & . & 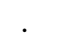 & . \\
\hline Acy-COX1-TH03 & . & $\mathrm{T}$ & . & . & . & . & . & 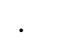 & & . & & . \\
\hline Acy-COX1-TH04 & . & . & . & . & . & G & . & & A & A & & . \\
\hline Асу-COX1-TH05 & . & . & & $\mathrm{C}$ & - & & 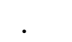 & . & & & & . \\
\hline Асу-COX1-TH06 & . & $\mathrm{T}$ & G & . & G & & A & & & . & G & A \\
\hline Асу-COX1-TH07 & . & . & & . & 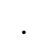 & . & & $\mathrm{T}$ & & . & & . \\
\hline Асу-COX1-TH08 & . & . & G & . & . & . & . & . & . & . & & . \\
\hline Асу-COX1-TH09 & G & . & . & . & . & . & . & . & . & . & . & . \\
\hline
\end{tabular}

The distribution and frequencies of A. ceylanicum haplotypes in Upper Northern Thailand were analyzed and revealed that the Acy-COX1-TH01 haplotype was detected at the highest frequency at $74.2 \%$ (23/31 sequences). This haplotype was commonly observed in all four provinces and found in both fecal and soil samples. As displayed in Figure 2, the sequence of two soil isolates (Acy-COX1-TH01-soil) was close to Acy-COX1-TH01-dog. Six haplotypes are present in Chiang Mai (Acy-COX1-TH01 to TH06), 3 haplotypes are present in Lampang (Acy-COX1-TH01, TH08, and TH09), whereas only one or two haplotypes were observed in Chiang Rai (Acy-COX1-TH01 and TH07) and Phayao (Acy-COX1-TH01) provinces (Table S5). Regarding the relationship among the human and animal isolates, Thai Acy-COX1-TH01 was close to the sequences of A. ceylanicum from Malaysian people (MK792828), dog (MK792824), and cat (MK792825) that belong to the same haplotype MA02 (Figure 2 and Table S1). Similarly, Acy-COX1-TH03 was close to the sequences of A. ceylanicum from human (KC247737) and $\operatorname{dog}$ (KC247734) that belong to the haplotype Malaysian MA01. Regarding the relationship between $A$. ceylanicum and geographic distribution, a phylogenetic tree demonstrated that A. ceylanicum from Thailand and all reference countries, including Malaysia, Cambodia, China, Japan, Papua New Guinea, and one country from the African continent (Tanzania), were located in the same clade, with the exception of one human sequence in Australia (AJ407937) (Figure 2).

\subsection{Population Analyses of the A. ceylanicum Mitochondrial cox1 Gene among Asian Countries}

The haplotype network displayed a star-like pattern and exhibited a wide dispersal around the predominant haplotype Acy-COX1-TH01 (in this study). This haplotype was identical to haplotypes MA02 from Malaysia, CA01 from Cambodia, and CH01 haplotype from China (Figure 3). The second most abundant haplotype was Acy-COX1-TH03, which was placed in the same group as haplotype MA01 from Malaysia and haplotype CA03 from Cambodia. Acy-COX1-TH06 was the most distinct haplotype, which includes four nucleotide-substitutions and was delineated from the haplotype CA02 from Cambodia.

The genetic diversity of the Thai $A$. ceylanicum population has been analyzed and compared pairwise to the populations of Cambodia, Malaysia, and China. The Thai A. ceylanicum cox1 population (32 sequences; 31 from this study and 1 sequence from Inpankaew et al. [33]) displayed the lowest genetic diversity-i.e., a haplotype diversity $(\mathrm{Hd})$ of 0.4435 and a nucleotide diversity $(\pi)$ of 0.0036 (Table 3). 


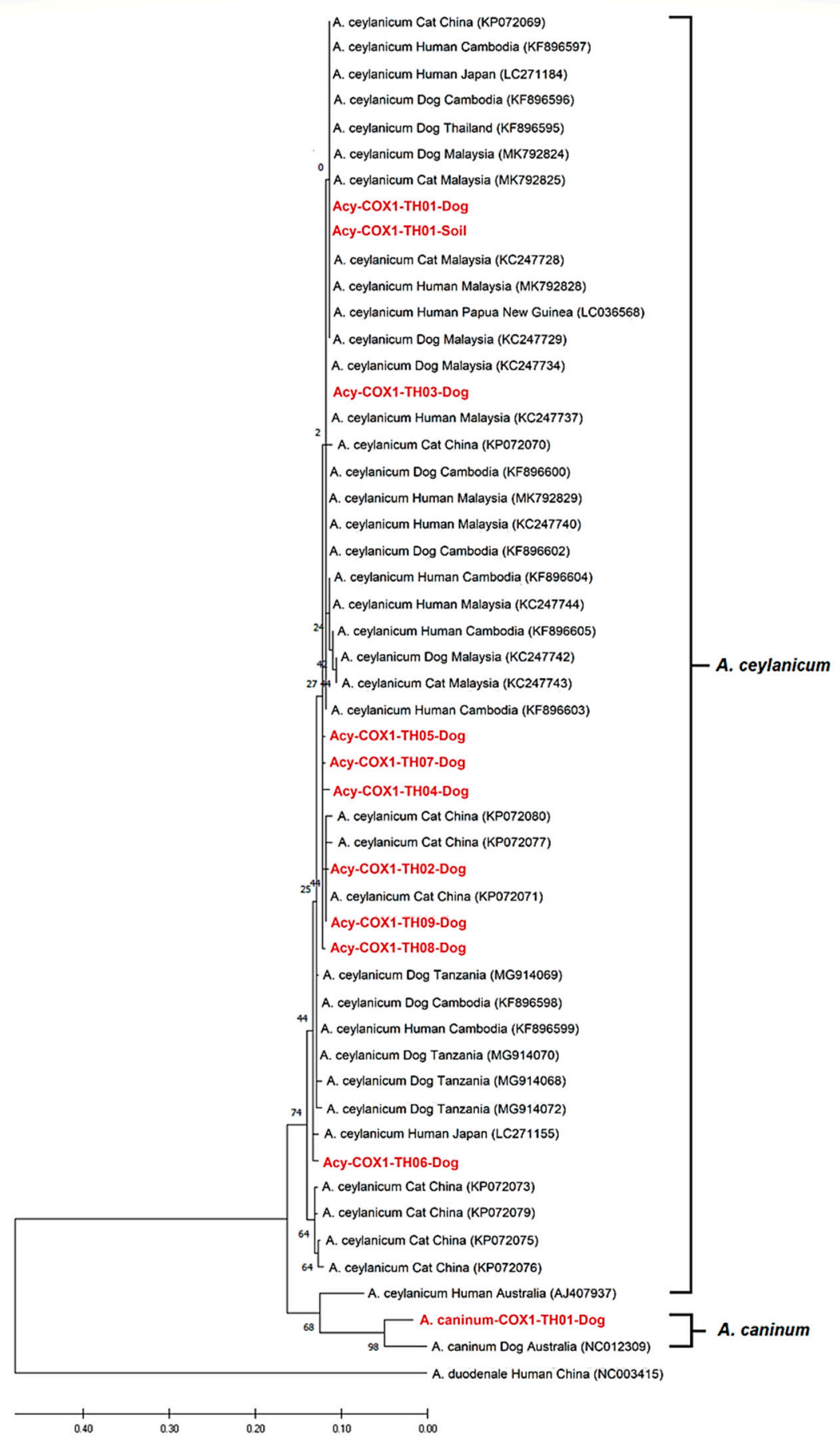

Figure 2. The evolutionary relationship of A. ceylanicum and A. caninum isolates from dogs and soil based on the 259-bp fragments of the mitochondrial cytochrome $c$ oxidase subunit 1 (cox1) gene. The tree was constructed using a maximum likelihood method based on the Kimura 2-Parameter using the MEGA X software version 10.0.5. The number in each branch indicates the percentage of 1000 bootstrap replications. Sequences obtained from GenBank are indicated by their accession numbers. 


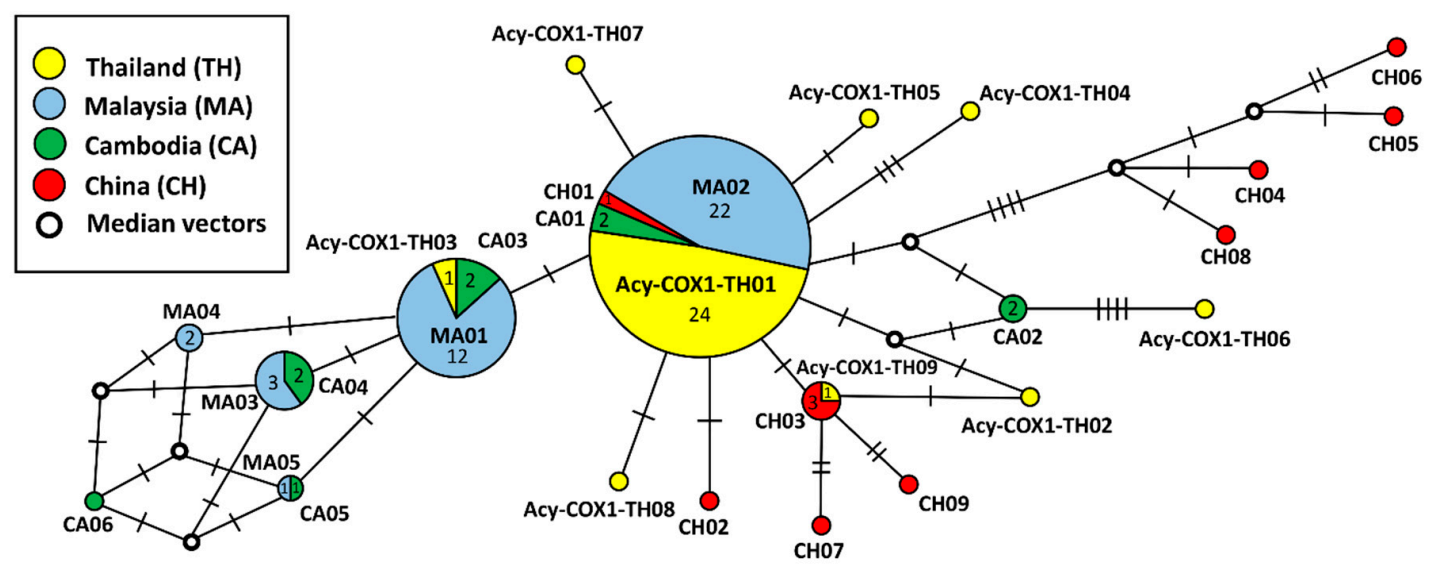

Figure 3. The haplotype network map of A. ceylanicum based on a fragment of the cox1 gene from Thailand, Cambodia, China, and Malaysia. Circle size is scaled to frequencies of each haplotype. The hash marks indicate nucleotide substitutions among adjacent haplotypes.

Table 3. Summary of the genetic diversity of the 4 populations of A. ceylanicum based on the nucleotide sequences of the partial mitochondrial cox 1 gene.

\begin{tabular}{cccccc}
\hline \multirow{2}{*}{ Populations } & \multirow{N}{*}{} & \multicolumn{4}{c}{ Diversity } \\
\cline { 3 - 6 } & & $\mathbf{S}$ & $\mathbf{h}$ & $\mathbf{H d} \pm \mathbf{S D}$ & $\boldsymbol{\pi} \pm \mathbf{S D}$ \\
\hline Thailand & 32 & 11 & 9 & $0.4435 \pm 0.1105$ & $0.0036 \pm 0.0028$ \\
Cambodia & 10 & 6 & 6 & $0.9111 \pm 0.0620$ & $0.0088 \pm 0.0059$ \\
Malaysia & 40 & 4 & 5 & $0.6141 \pm 0.0593$ & $0.0043 \pm 0.0006$ \\
China & 12 & 17 & 9 & $0.9394 \pm 0.0577$ & $0.0201 \pm 0.0118$ \\
\hline
\end{tabular}

$\mathrm{N}$ : numbers of A. ceylanicum sequences used; S: numbers of variable sites; h: numbers of haplotypes; Hd: haplotype diversity; SD: standard deviation; $\pi$ : nucleotide diversity.

The highest haplotype diversity and nucleotide diversity were observed in the Chinese A. ceylanicum population ( $\mathrm{Hd}=0.9394 ; \pi=0.0201)$, followed by the Cambodian and Malaysian populations. Pairwise $\left(\mathrm{F}_{\mathrm{ST}}\right)$ indices between the Thai $A$. ceylanicum population and other reference populations were $0.2644,0.2507$, and 0.1526 for the Chinese, Cambodian, and Malaysian populations, respectively. In addition, the highest $\mathrm{F}_{\mathrm{ST}}$ value of 0.3577 was observed between the Chinese and Malaysian populations. All the $\mathrm{F}_{\mathrm{ST}}$ values were statistically significant (Table 4).

Table 4. The pairwise fixation index $\left(\mathrm{F}_{\mathrm{ST}}\right)$ among four A. ceylanicum populations based on the partial mitochondrial cox1 gene.

\begin{tabular}{ccccc}
\hline Populations & Thailand & Cambodia & Malaysia & China \\
\hline Thailand & - & & & \\
Cambodia & 0.2507 & - & & \\
Malaysia & 0.1526 & 0.0999 & - & \\
China & 0.2644 & 0.1939 & 0.3577 & - \\
\hline \multicolumn{4}{c}{ All values were statistically significant $(p<0.001)}$.
\end{tabular}

\section{Discussion}

The major hookworm species in the community dogs in Upper Northern Thailand was A. ceylanicum. We demonstrated an approximately 50\% temple-level prevalence of hookworm infection in dogs, and these positive dogs were commonly living in the community temples and freely roaming in the surrounding communities. The prevalence of hookworm infection at the individual dog level in this study (26.4\%) showed an approximately two-fold increase compared with previous studies in Chiang 
Mai province (approximately 12\%), as reported by Tiwananthagorn et al. (unpublished results) and Tangtrongsup et al. [23], and greater than that reported by Pumidonming et al. [22] in Lower Northern Thailand $(21.3 \%)$. These differences are probably due to the different study areas and the inclusion criteria of no regular deworming program. The proportion of $A$. ceylanicum infection in dogs from our study in Upper Northern Thailand (96.6\%) was higher than the previous report in the Lower Northern region, which reported a rate of $82.1 \%$ [22]. Recently, various studies have reported the rate of A. ceylanicum in hookworm infection in the bordering countries of Thailand: $94.4 \%$ of dogs in Cambodia, 52\% of dogs in Malaysia [39], 77.8\% of dogs in Laos [40], and $42.7 \%$ of dogs in China [7]. The failure of PCR amplification in some fecal and soil samples was noticed in the present study and was also noted in other studies. This failure could be due to the low intensity of infection, resulting in a reduced number of hookworm eggs, and some PCR inhibitors in the fecal and soil samples interfere with the amplification reaction $[15,41]$. Therefore, developing a more robust PCR assay to improve the diagnosis of hookworm infection is needed for the efficient control of this zoonosis.

The temples with hookworm-infected dogs are prone to have hookworm-contaminated soil. Here, we confirmed the presence of A. ceylanicum larvae in the soil. Moreover, the A. ceylanicum genotypes in dogs and soil were identical, suggesting the shedding of hookworm from dogs to the soil. The frequently detected areas in the positive temples included the dog's dwelling areas; human activity areas, such as the sand pagoda; and the areas under the big tree. These areas are the places that community people commonly access for the Buddhist rituals, ceremonies, commerce, and recreation. In addition, allowing dogs to roam freely with indiscriminate defecating areas in the Thai temples can lead to the widespread contamination of infective A. ceylanicum hookworm larvae in the environment and possible transmission to humans who occasionally go barefoot during these activities. As suggested in rural Malaysia, close contact with community dogs and cats was associated with A. ceylanicum hookworm infection in humans [42]. Previous reports worldwide have reported soil contaminated with hookworm in the public parks of Brazil and Malaysia [43,44], a tribal area of India [5], dog parks in Portugal [45], and organic farms in the Philippines [46]. Therefore, good hygienic practices of shoe-wearing and temple ground cleaning programs should be encouraged to reduce the risk of transmission [47]. In addition, reducing the number of free-roaming dog population size through a sterilization campaign or by sheltering free-roaming dogs should be implemented [48].

The molecular epidemiologic data, phylogenetic relationship, and population analysis obtained from the characterization of the cox 1 gene of $A$. ceylanicum hookworms strongly support the distribution of this parasite in the country, within the Asian continent, and possibly worldwide. A common haplotype of Thailand (Acy-COX1-TH01), which was observed in all four provinces of Upper Northern Thailand, suggested the circulation of $A$. ceylanicum in the region. Genetic differentiation analysis showed that Thai A. ceylanicum had the lowest haplotype diversity and nucleotide diversity, indicating minimal differences between haplotypes in Thailand. However, further studies in other regions of Thailand are necessary. The pairwise fixation index showed that Thai A. ceylanicum was mostly close to Malaysian A. ceylanicum, suggesting gene flow between these populations. In addition, the sharing haplotype of the cox1 gene of A. ceylanicum among the countries (Acy-COX1-TH01 and MA02 and CA01 and CH01; or Acy-COX1-TH03 and MA01 and CA03) advocated the transmission and widespread geographic distribution among these countries [49]. The haplotype relationship between Malaysia and Cambodia populations revealed a very complex evolutionary pattern with some median vectors that indicated many lost or potential ancestors [50]. Interestingly, the Chinese A. ceylanicum exhibited the highest haplotype and nucleotide diversities, suggesting that the Chinese A. ceylanicum might be an ancestor of the populations in Asian countries. Our hypothesis is consistent with a previous study on the history of domestic dogs, in which China was the origin of the dog species [51]. Animals potentially migrated to accompany human colonization to other Asian countries and subsequently carried the parasites and allowed the parasites to colonize new habitats [51-53]. Hence, the transportation of companion animals should strictly follow the guidelines and regulations of each county to prevent the spreading of zoonotic hookworm. 
Based on the phylogenetic tree, the sequences of A. ceylanicum from humans (MK792828-29), dogs (MK792824), and cats (MK792825) in Malaysia belong to the same haplotype MA02, confirming that transmission from dogs to humans has occurred. This species was also found in wildlife, such as Asian golden cat, leopard cat, civet, and wild canids [9,54,55]. The biological, epidemiological, and pathophysiological characteristics of A. ceylanicum in humans and other wildlife species in Thailand and their genetic diversity with isolates from companion animals deserve further investigation.

Integrated control programs intended for combining chemotherapeutic interventions by deworming programs with improvements in community hygiene and animal health programs will aid in curbing this potentially opportunistic zoonosis. For the deworming program of community dogs in Thailand, an oral dose of $10 \mathrm{mg} / \mathrm{kg}$ BW of pyrantel pamoate and the subcutaneous injection of $0.2-0.4 \mathrm{mg} / \mathrm{kg}$ BW ivermectin have been regularly administered for deworming; however, the efficacy of these regimens against $A$. ceylanicum in dogs remains unclear. Currently, many commercial drugs against $A$. ceylanicum infection in dogs have been tested at the laboratory level and exhibited greater than $99 \%$ efficacy within 3-7 days, including a combination of $15 \mathrm{mg} / \mathrm{kg}$ BW of febantel and $14.4 \mathrm{mg} / \mathrm{kg} \mathrm{BW}$ of pyrantel embonate (Drontal ${ }^{\circledR}$ Plus, Bayer Animal health) [56], a spot-on of $2.5 \mathrm{mg} / \mathrm{kg} \mathrm{BW}$ moxidectin (Advocate ${ }^{\circledR}$, Bayer Animal health) [57], and $0.5 \mathrm{mg} / \mathrm{kg}$ BW milbemycin oxime (NexGard Spectra ${ }^{\circledR}$, Boehringer Ingelheim) [58]. The clinical field assessment of the efficacy of anthelminthic agents against A. ceylanicum infection warrants further investigation.

\section{Conclusions}

In conclusion, this study provided the data, genetic characteristics, and evolutionary relationship of A. ceylanicum in Thailand and other Asian countries. We confirmed that $A$. ceylanicum was the predominant hookworm species in Northern Thailand, and the data fully supported the transmission dynamics from dogs to soil environments. Therefore, the awareness of A. ceylanicum transmission from dogs and soil in the temple should be raised. A proper schedule for the deworming of community dogs and the regular cleaning of the temple ground are suggested to reduce the risk of transmission of this zoonotic disease.

Supplementary Materials: The following are available online at http://www.mdpi.com/2076-2615/10/11/2154/s1: Table S1: Reference Ancylostoma cox1 gene sequences used for phylogenetic analysis, Table S2: List of A. ceylanicum haplotypes based on a 259-bp fragment of the cox1 gene by countries for population analysis, Table S3: Summary of hookworm infection in dog fecal samples and soil samples obtained from 53 temples as assessed by microscopic examination, Table S4: Hookworm detection in the soil based on the site of collection in temples in Thailand, Table S5: Haplotypes of Ancylostoma hookworms based onthe cox1 gene in Thailand based on sampling location.

Author Contributions: Conceptualization, S.T. (Saruda Tiwananthagorn); methodology, D.K., S.T. (Sahatchai Tangtrongsup), and S.T. (Saruda Tiwananthagorn); software, D.K., S.T. (Sahatchai Tangtrongsup), and S.T. (Saruda Tiwananthagorn); validation, S.T. (Sahatchai Tangtrongsup), and S.T. (Saruda Tiwananthagorn); formal analysis, D.K., S.T. (Sahatchai Tangtrongsup), and S.T. (Saruda Tiwananthagorn); investigation, D.K. and S.T. (Saruda Tiwananthagorn); resources, D.K. and S.T. (Saruda Tiwananthagorn); data curation, D.K., S.T. (Sahatchai Tangtrongsup), and S.T. (Saruda Tiwananthagorn); writing-original draft preparation, D.K., S.T. (Sahatchai Tangtrongsup), and S.T. (Saruda Tiwananthagorn); writing-review and editing, S.T. (Sahatchai Tangtrongsup) and S.T. (Saruda Tiwananthagorn); visualization, S.T. (Saruda Tiwananthagorn); supervision, S.T. (Sahatchai Tangtrongsup) and S.T. (Saruda Tiwananthagorn); project administration, S.T. (Saruda Tiwananthagorn); funding acquisition, S.T. (Saruda Tiwananthagorn). All authors have read and agreed to the published version of the manuscript.

Funding: This study was supported by the Excellent Center of Veterinary Bioscience, Faculty of Veterinary Medicine, Chiang Mai University and the research project "A multicenter study of dog and cat parasites in East and Southeast Asia; R000017642".

Acknowledgments: We would like to thank all the community dog owners for their valuable participation and the excellent assistance of Mrs. Duanghatai Sripakdee, Parasitological laboratory of Faculty of Veterinary Medicine, Chiang Mai University.

Conflicts of Interest: The authors declare no conflict of interest. 


\section{References}

1. Liu, Y.; Shen, Y.; Zhang, T. Survey of the relationship between hookworm disease and socioeconomic factors. Zhongguo Ji Sheng Chong Xue Yu Ji Sheng Chong Bing Za Zhi 1999, 17, 399. [PubMed]

2. Bethony, J.; Brooker, S.; Albonico, M.; Geiger, S.M.; Loukas, A.; Diemert, D.; Hotez, P.J. Soil-transmitted helminth infections: Ascariasis, trichuriasis, and hookworm. Lancet 2006, 367, 1521-1532. [CrossRef]

3. Merino-Tejedor, A.; Nejsum, P.; Mkupasi, E.M.; Johansen, M.V.; Olsen, A. Molecular identification of zoonotic hookworm species in dog faeces from Tanzania. J. Helminthol. 2019, 93, 313-318. [CrossRef] [PubMed]

4. Gordon, C.A.; Kurscheid, J.; Jones, M.K.; Gray, D.J.; McManus, D.P. Soil-transmitted helminths in tropical Australia and Asia. Trop. Med. Infect. Dis. 2017, 4, 56. [CrossRef] [PubMed]

5. George, S.; Levecke, B.; Kattula, D.; Velusamy, V.; Roy, S.; Geldhof, P.; Sarkar, R.; Kang, G. Molecular identification of hookworm isolates in humans, dogs and soil in a tribal area in Tamil Nadu, India. PLoS Negl. Trop. Dis. 2016, 10, e0004891. [CrossRef]

6. Bowman, D.D.; Montgomery, S.P.; Zajac, A.M.; Eberhard, M.L.; Kazacos, K.R. Hookworms of dogs and cats as agents of cutaneous larva migrans. Trends Parasitol. 2010, 26, 162-167. [CrossRef] [PubMed]

7. Liu, Y.J.; Zheng, G.C.; Zhang, P.; Alsarakibi, M.; Zhang, X.H.; Li, Y.W.; Liu, T.; Ren, S.N.; Chen, Z.X.; Liu, Y.L.; et al. Molecular identification of hookworms in stray and shelter dogs from Guangzhou city, China using ITS sequences. J. Helminthol. 2015, 89, 196-202. [CrossRef]

8. Smout, F.A.; Skerratt, L.F.; Butler, J.R.A.; Johnson, C.N.; Congdon, B.C.; Thompson, R.C.A. The hookworm Ancylostoma ceylanicum: An emerging public health risk in Australian tropical rainforests and Indigenous communities. One Health 2017, 3, 66-69. [CrossRef]

9. Zibaei, M.; Nosrati, M.R.C.; Shadnoosh, F.; Houshmand, E.; Karami, M.F.; Rafsanjani, M.K.; Majidiani, H.; Ghaffarifar, F.; Cortes, H.C.E.; Dalvand, S.; et al. Insights into hookworm prevalence in Asia: A systematic review and meta-analysis. Trans. R. Soc. Trop. Med. Hyg. 2020, 114, 141-154. [CrossRef]

10. Palmer, C.S.; Traub, R.J.; Robertson, I.D.; Hobbs, R.P.; Elliot, A.; While, L.; Rees, R.; Thompson, R.C. The veterinary and public health significance of hookworm in dogs and cats in Australia and the status of A. ceylanicum. Vet. Parasitol. 2007, 145, 304-313. [CrossRef]

11. Traub, R.J. Ancylostoma ceylanicum, a re-emerging but neglected parasitic zoonosis. Int. J. Parasitol. 2013, 43, 1009-1015. [CrossRef] [PubMed]

12. Schar, F.; Inpankaew, T.; Traub, R.J.; Khieu, V.; Dalsgaard, A.; Chimnoi, W.; Chhoun, C.; Sok, D.; Marti, H.; Muth, S.; et al. The prevalence and diversity of intestinal parasitic infections in humans and domestic animals in a rural Cambodian village. Parasitol. Int. 2014, 63, 597-603. [CrossRef] [PubMed]

13. Kaya, D.; Yoshikawa, M.; Nakatani, T.; Tomo-Oka, F.; Fujimoto, Y.; Ishida, K.; Fujinaga, Y.; Aihara, Y.; Nagamatsu, S.; Matsuo, E.; et al. Ancylostoma ceylanicum hookworm infection in Japanese traveler who presented chronic diarrhea after return from Lao People's Democratic Republic. Parasitol. Int. 2016, 65, 737-740. [CrossRef] [PubMed]

14. Yoshikawa, M.; Ouji, Y.; Hirai, N.; Nakamura-Uchiyama, F.; Yamada, M.; Arizono, N.; Akamatsu, N.; Yoh, T.; Kaya, D.; Nakatani, T.; et al. Ancylostoma ceylanicum, novel etiological agent for traveler's diarrhea-report of four Japanese patients who returned from southeast Asia and Papua New Guinea. Trop. Med. Health 2018, 46, 6. [CrossRef] [PubMed]

15. Ngui, R.; Ching, L.S.; Kai, T.T.; Roslan, M.A.; Lim, Y.A. Molecular identification of human hookworm infections in economically disadvantaged communities in Peninsular Malaysia. Am. J. Trop. Med. Hyg. 2012, 86, 837-842. [CrossRef]

16. Traub, R.J.; Robertson, I.D.; Irwin, P.; Mencke, N.; Thompson, R.C. Application of a species-specific PCR-RFLP to identify Ancylostoma eggs directly from canine faeces. Vet. Parasitol. 2004, 123, 245-255. [CrossRef]

17. Romstad, A.; Gasser, R.B.; Nansen, P.; Polderman, A.M.; Chilton, N.B. Necator americanus (Nematoda: Ancylostomatidae) from Africa and Malaysia have different ITS-2 rDNA sequences. Int. J. Parasitol. 1998, 28, 611-615. [CrossRef]

18. Gasser, R.B.; Stewart, L.E.; Speare, R. Genetic markers in ribosomal DNA for hookworm identification. Acta Trop. 1996, 62, 15-21. [CrossRef] 
19. Blouin, M.S. Molecular prospecting for cryptic species of nematodes: Mitochondrial DNA versus internal transcribed spacer. Int. J. Parasitol. 2002, 32, 527-531. [CrossRef]

20. Hu, M.; Chilton, N.B.; Gasser, R.B. The mitochondrial genomics of parasitic nematodes of socio-economic importance: Recent progress, and implications for population genetics and systematics. Adv. Parasitol. 2004, 56, 133-212. [CrossRef]

21. Avise, J.C.; Arnold, J.; Ball, R.M.; Bermingham, E.; Lamb, T.; Neigel, J.E.; Reeb, C.A.; Saunders, N.C. Intraspecific phylogeography: The mitochondrial DNA bridge between population genetics and systematics. Annu. Rev. Ecol. Syst. 1987, 18, 489-522. [CrossRef]

22. Pumidonming, W.; Salman, D.; Gronsang, D.; Abdelbaset, A.E.; Sangkaeo, K.; Kawazu, S.I.; Igarashi, M. Prevalence of gastrointestinal helminth parasites of zoonotic significance in dogs and cats in lower Northern Thailand. J. Vet. Med. Sci. 2017, 78, 1779-1784. [CrossRef]

23. Tangtrongsup, S.; Scorza, A.V.; Reif, J.S.; Ballweber, L.R.; Lappin, M.R.; Salman, M.D. Seasonal distributions and other risk factors for Giardia duodenalis and Cryptosporidium spp. infections in dogs and cats in Chiang Mai, Thailand. Prev. Vet. Med. 2020, 174, 104820. [CrossRef] [PubMed]

24. Piangjai, S.; Sukontason, K.; Sukontason, K.L. Intestinal parasitic infections in hill-tribe schoolchildren in Chiang Mai, northern Thailand. Southeast Asian J. Trop. Med. Public Health 2003, 34 (Suppl. 2), 90-93.

25. Yanola, J.; Nachaiwieng, W.; Duangmano, S.; Prasannarong, M.; Somboon, P.; Pornprasert, S. Current prevalence of intestinal parasitic infections and their impact on hematological and nutritional status among Karen hill tribe children in Omkoi District, Chiang Mai Province, Thailand. Acta Trop. 2018, 180, 1-6. [CrossRef] [PubMed]

26. Energy Policy and Plannning Office, Ministry of Energy. The Provinces and Administrative Areas of Thailand. Available online: http://www.e-report.energy.go.th/area.html (accessed on 31 May 2019).

27. Royal Thai Government Gazette, The Secretariat of the Cabinet. Thailand Population. 2018. Available online: http://www.ratchakitcha.soc.go.th/DATA/PDF/2562/E/036/T_0032.PDF (accessed on 31 May 2019).

28. Thrusfield, M.; Ortega, C.; de Blas, I.; Noordhuizen, J.P.; Frankena, K. WIN EPISCOPE 2.0: Improved epidemiological software for veterinary medicine. Vet. Rec. 2001, 148, 567-572. [CrossRef] [PubMed]

29. Tiwananthagorn, S.; Chiang Mai University, Chiang Mai, Thailand. Unpublished Work. 2018.

30. Bureau of Disease Control and Veterinary Services, Department of Livestock Development. Dog Population in Thailand. 2016. Available online: http://dcontrol.dld.go.th/webnew/index.php/th/news-menu/2018-07-0404-12-47/rabies/360-dogpop2016 (accessed on 31 May 2019).

31. Moxham, G. The WALTHAM faeces scoring system-A tool for veterinarians and pet owners: How does your pet rate? Walth. Focus 2001, 11, 24-25.

32. Gibbons, L.M.; Jones, A.; Khalil, L.F. Manual for the 8th International Training Course on Identification of Helminth Parasites of Economic Importance; CABI Institue of Parasitology, Wallingford: Oxon, UK, 1996.

33. Inpankaew, T.; Schar, F.; Dalsgaard, A.; Khieu, V.; Chimnoi, W.; Chhoun, C.; Sok, D.; Marti, H.; Muth, S.; Odermatt, P.; et al. High prevalence of Ancylostoma ceylanicum hookworm infections in humans, Cambodia, 2012. Emerg. Infect. Dis. 2014, 20, 976-982. [CrossRef]

34. Hall, T. BioEdit: A user-friendly biological sequence alignment editor and analysis program for Window 95/98/NT. Nucleic Acids Symp. Ser. 1996, 41, 95-98.

35. Kumar, S.; Stecher, G.; Li, M.; Knyaz, C.; Tamura, K. MEGA X: Molecular evolutionary genetics analysis across computing platforms. Mol. Biol. Evol. 2018, 35, 1547-1549. [CrossRef]

36. Rozas, J.; Ferrer-Mata, A.; Sanchez-DelBarrio, J.C.; Guirao-Rico, S.; Librado, P.; Ramos-Onsins, S.E.; Sanchez-Gracia, A. DnaSP 6: DNA sequence polymorphism analysis of large data sets. Mol. Biol. Evol. 2017, 34, 3299-3302. [CrossRef] [PubMed]

37. Excoffier, L.; Lischer, H.E. Arlequin suite ver 3.5: A new series of programs to perform population genetics analyses under Linux and Windows. Mol. Ecol. Resour. 2010, 10, 564-567. [CrossRef] [PubMed]

38. Bandelt, H.J.; Forster, P.; Rohl, A. Median-joining networks for inferring intraspecific phylogenies. Mol. Biol. Evol. 1999, 16, 37-48. [CrossRef] [PubMed] 
39. Mahdy, M.A.; Lim, Y.A.; Ngui, R.; Siti Fatimah, M.R.; Choy, S.H.; Yap, N.J.; Al-Mekhlafi, H.M.; Ibrahim, J.; Surin, J. Prevalence and zoonotic potential of canine hookworms in Malaysia. Parasit Vectors 2012, 5, 88. [CrossRef]

40. Conlan, J.V.; Khamlome, B.; Vongxay, K.; Elliot, A.; Pallant, L.; Sripa, B.; Blacksell, S.D.; Fenwick, S.; Thompson, R.C. Soil-transmitted helminthiasis in Laos: A community-wide cross-sectional study of humans and dogs in a mass drug administration environment. Am. J. Trop. Med. Hyg. 2012, 86, 624-634. [CrossRef]

41. Schrader, C.; Schielke, A.; Ellerbroek, L.; Johne, R. PCR inhibitors-occurrence, properties and removal. J. Appl. Microbiol. 2012, 113, 1014-1026. [CrossRef]

42. Ngui, R.; Mahdy, M.A.; Chua, K.H.; Traub, R.; Lim, Y.A. Genetic characterization of the partial mitochondrial cytochrome oxidase $c$ subunit I (cox1) gene of the zoonotic parasitic nematode, Ancylostoma ceylanicum from humans, dogs and cats. Acta Trop. 2013, 128, 154-157. [CrossRef]

43. Marques, J.P.; Guimaraes Cde, R.; Boas, A.V.; Carnauba, P.U.; Moraes, J. Contamination of public parks and squares from Guarulhos (Sao Paulo State, Brazil ) by Toxocara spp. and Ancylostoma spp. Rev. Inst. Med. Trop. Sao Paulo 2012, 54, 267-271. [CrossRef]

44. Tun, S.; Ithoi, I.; Mahmud, R.; Samsudin, N.I.; Kek Heng, C.; Ling, L.Y. Detection of helminth eggs and identification of hookworm species in stray cats, dogs and soil from Klang Valley, Malaysia. PLoS ONE 2015, 10, e0142231. [CrossRef]

45. Ferreira, A.; Alho, A.M.; Otero, D.; Gomes, L.; Nijsse, R.; Overgaauw, P.A.M.; Madeira de Carvalho, L. Urban dog parks as sources of canine parasites: Contamination rates and pet owner behaviours in Lisbon, Portugal. J. Env. Public Health 2017, 2017, 5984086. [CrossRef]

46. Paller, V.G.V.; Babia-Abion, S. Soil-transmitted helminth (STH) eggs contaminating soils in selected organic and conventional farms in the Philippines. Parasite Epidemiol. Control. 2019, 7, e00119. [CrossRef]

47. Traub, R.J.; Inpankaew, T.; Sutthikornchai, C.; Sukthana, Y.; Thompson, R.C. PCR-based coprodiagnostic tools reveal dogs as reservoirs of zoonotic ancylostomiasis caused by Ancylostoma ceylanicum in temple communities in Bangkok. Vet. Parasitol. 2008, 155, 67-73. [CrossRef]

48. Smith, L.M.; Hartmann, S.; Munteanu, A.M.; Dalla Villa, P.; Quinnell, R.J.; Collins, L.M. The effectiveness of dog population management: A systematic review. Animals 2019, 9, 1020. [CrossRef] [PubMed]

49. Posada, D.; Crandall, K.A. Intraspecific gene genealogies: Trees grafting into networks. Trends Ecol. Evol. 2001, 16, 37-45. [CrossRef]

50. Guo, L.; Sun, B.; Sang, F.; Wang, W.; Lu, Z. Haplotype distribution and evolutionary pattern of miR-17 and miR-124 families based on population analysis. PLoS ONE 2009, 4, e7944. [CrossRef] [PubMed]

51. Wang, G.D.; Zhai, W.; Yang, H.C.; Wang, L.; Zhong, L.; Liu, Y.H.; Fan, R.X.; Yin, T.T.; Zhu, C.L.; Poyarkov, A.D.; et al. Out of southern East Asia: The natural history of domestic dogs across the world. Cell Res. 2016, 26, 21-33. [CrossRef] [PubMed]

52. Witt, K.E.; Judd, K.; Kitchen, A.; Grier, C.; Kohler, T.A.; Ortman, S.G.; Kemp, B.M.; Malhi, R.S. DNA analysis of ancient dogs of the Americas: Identifying possible founding haplotypes and reconstructing population histories. J. Hum. Evol. 2015, 79, 105-118. [CrossRef] [PubMed]

53. Loeurng, V.; Ichikawa-Seki, M.; Wannasan, A.; Sothyra, T.; Chaisowwong, W.; Tiwananthagorn, S. Genetic characterization of cambodian Fasciola gigantica and dispersal direction of the species in Asia. Vet. Parasitol. 2019, 273, 45-51. [CrossRef]

54. Biocca, E.; Chabaud, A. Redescription of Seuratum mucronatum (Nematoda-Cucullanidae). Ann. Parasitol. Hum. Comp. 1951, 26, 85-92. [CrossRef]

55. Smout, F.A.; Thompson, R.C.; Skerratt, L.F. First report of Ancylostoma ceylanicum in wild canids. Int. J. Parasitol. Parasites Wildl. 2013, 2, 173-177. [CrossRef]

56. Taweethavonsawat, P.; Chungpivat, S.; Satranarakun, P.; Traub, R.J.; Schaper, R. Efficacy of a combination product containing pyrantel, febantel and praziquantel (Drontal ${ }^{\circledR}$ Plus Flavour, Bayer Animal Health) against experimental infection with the hookworm Ancylostoma ceylanicum in dogs. Parasitol. Res. 2010, 106, 533-537. [CrossRef] [PubMed] 
57. Taweethavonsawat, P.; Chungpivat, S.; Satranarakun, P.; Traub, R.J.; Schaper, R. Experimental infection with Ancylostoma ceylanicum in dogs and efficacy of a spot on combination containing imidacloprid $10 \%$ and moxidectin 2.5\% (Advocate ${ }^{\circledR} /$ Advantage Multi, Bayer Animal Health). Parasitol. Res. 2010, 106, 1499-1502. [CrossRef] [PubMed]

58. Tielemans, E.; Lebon, W.; Dumont, P.; Taweethavonsawat, P.; Larsen, D.; Rehbein, S. Efficacy of afoxolaner plus milbemycin oxime chewable tablets (NexGard Spectra ${ }^{\circledR}$, Merial) against adult Ancylostoma ceylanicum hookworm, in dogs. Vet. Parasitol. 2017, 238, 87-89. [CrossRef] [PubMed]

Publisher's Note: MDPI stays neutral with regard to jurisdictional claims in published maps and institutional affiliations.

(C) 2020 by the authors. Licensee MDPI, Basel, Switzerland. This article is an open access article distributed under the terms and conditions of the Creative Commons Attribution (CC BY) license (http://creativecommons.org/licenses/by/4.0/). 